\title{
The Cellular Oncogene c-myb Can Interact Synergistically with the Epstein-Barr Virus BZLF1 Transactivator in Lymphoid Cells
}

\author{
SHANNON C. KENNEY, ${ }^{1 *}$ ELIZABETH HOLLEY-GUTHRIE, ${ }^{1}$ E. BYRD QUINLIVAN, ${ }^{1}$ DAVID GUTSCH, ${ }^{1}$ \\ QIN ZHANG, ${ }^{1}$ TIM BENDER,${ }^{2}$ JEAN-FRANCOIS GIOT ${ }^{3}$ AND ALAIN SERGEANT ${ }^{3}$ \\ Department of Medicine and Lineberger Comprehensive Cancer Research Center, University of North Carolina \\ at Chapel Hill, Chapel Hill, North Carolina 27599'; University of Virginia, Charlottesville, Virginia 229032 \\ and Laboratoire de Virologie Moleculaire, Ecole Normale Superieure de Lyon, Lyon, France ${ }^{3}$
}

Received 3 May 1991/Accepted 4 October 1991

\begin{abstract}
Regulation of replicative functions in the Epstein-Barr virus (EBV) genome is mediated through activation of a virally encoded transcription factor, $Z$ (BZLF1). We have shown that the $Z$ gene product, which binds to AP-1 sites as a homodimer and has sequence similarity to c-Fos, can efficiently activate the EBV early promoter, BMRF1, in certain cell types (i.e., HeLa cells) but not others (i.e., Jurkat cells). Here we demonstrate that the c-myb proto-oncogene product, which is itself a DNA-binding protein and transcriptional transactivator, can interact synergistically with $Z$ in activating the BMRF1 promoter in Jurkat cells (a T-cell line) or Raji cells (an EBV-positive B-cell), whereas the c-myb gene product by itself has little effect. The simian virus $\mathbf{4 0}$ early promoter is also synergistically activated by the $\mathbf{Z} / c$-myb combination. Synergistic transactivation of the BMRF1 promoter by the $Z / c-m y b$ combination appears to involve direct binding by the $Z$ protein but not the c-myb protein. A 30-bp sequence in the BMRF1 promoter which contains a $Z$ binding site (a consensus AP-1 site) is sufficient to transfer high-level lymphoid-specific responsiveness to the $Z / c-m y b$ combination to a heterologous promoter. That the c-myb oncogene product can interact synergistically with an EBV-encoded member of the leucine zipper protein family suggests $c-m y b$ is likely to engage in similar interactions with cellularly encoded transcription factors.
\end{abstract}

The discovery that expression of a single Epstein-Barr virus (EBV) immediate-early (IE) gene product, BZLF1 (Z), is sufficient to trigger the disruption of viral latency $(6,7,44$, 48) has stimulated a search for the key cellular and viral elements needed to activate EBV replication. It is now clear that the $\mathrm{Z}$ gene product has significant sequence similarity to the DNA binding domain of c-Fos (11). The $\mathrm{Z}$ protein, like c-Fos, can bind to the AP-1 site, but in contrast to c-Fos, $\mathrm{Z}$ binds as a homodimer and can also bind to additional non-AP-1 sites referred to as $\mathrm{Z}$ response elements (ZREs) $(4$, $11,13,29,35,43,45,50,55)$.

To date, transcriptional activation of early EBV promoters by $\mathrm{Z}$ has been associated with the presence of $\mathrm{Z}$ binding sites in upstream promoter elements. However, we recently reported that the EBV early BMRF1 promoter, which contains a consensus AP-1 binding site, is transactivated efficiently by $\mathrm{Z}$ in certain epithelial cell lines (including $\mathrm{HeLa}$ and HEp-2 cells) but not in several lymphoid cell lines (including the Jurkat T-cell line and the EBV-negative B-cell line Louckes) (21). Therefore, it seems likely that cellular factors, as well as $\mathrm{Z}$ itself, are required for efficient transactivation of Z-responsive promoters.

Here we report the first evidence that the cellular c-myb oncogene can interact synergistically with the $\mathrm{Z}$ transactivator in lymphoid cells. The c-myb gene is the cellular homolog of the v-myb oncogene and encodes a 75-kDa nuclear protein (reviewed in reference 38). The v-myb oncogene is carried by the avian myeloblastosis virus and transforms myeloid, but not fibroblast, cells (25). Although $c-m y b$ is predominantly expressed in immature hematopoietic cells, it is expressed at lesser levels in other cell types $(1,37,42,51$, $52)$. It has been recently shown that the c-myb protein binds

\footnotetext{
* Corresponding author.
}

specifically to the nucleotide sequence pyAACG/TG and can activate promoters carrying multiple copies of this sequence $(2,14,22,24,28,41,59)$. However, there is some evidence to suggest that transcriptional activation by c-myb may require interaction with other transcriptional activators. Ibanez and Lipsick (24) have reported that $\mathrm{v}$-Myb binding is required, but apparently not sufficient, for activation of target promoters containing several copies of the consensus Myb binding site. Furthermore, v- $m y b$-induced transactivation of certain promoters has been reported to occur through a nonbinding mechanism (27).

In addition to the c-myb protein, cDNA clones of two closely related proteins, $\mathrm{A}-\mathrm{Myb}$ and $\mathrm{B}-\mathrm{Myb}$, have been isolated (42). The A-myb and B-myb proteins, which are expressed at high level in a wider variety of tissues than is $\mathrm{c}-\mathrm{Myb}$, have DNA binding domains very similar to that of c-Myb (42). It has recently been confirmed that the B-myb protein, like c-Myb, can bind to the consensus c-myb binding site and function as a transcriptional activator (39). In addition, there are several different splicing variants of $\mathrm{c}-\mathrm{Myb}$, some of which affect the regulatory sequences of the protein $(47,57,58)$. Transcriptional regulation of promoters containing Myb binding sites is therefore likely to be cell type specific, depending on the relative proportions of the different $m y b$ proteins in each cell type.

Here we show that the EBV early BMRF1 promoter can be activated synergistically by the combination of $\mathrm{Z}$ and c-myb in Jurkat cells (a T-cell line) or Raji cells (an EBVpositive $\mathrm{B}$-cell line), whereas $\mathrm{Z}$ by itself efficiently activates the BMRF1 promoter in two different epithelial cell lines. We map the region of the BMRF1 promoter required for maximal response to the $\mathrm{Z} / \mathrm{c}-\mathrm{myb}$ combination to a 30 -bp stretch containing a consensus AP-1 site and show that this sequence is sufficient to confer responsiveness to the $\mathrm{Z} / \mathrm{c}$ $m y b$ combination to a heterologous promoter. The simian 
virus 40 (SV40) early promoter, which contains an AP-1 binding site (33), is also synergistically activated by the $\mathrm{Z} / \mathrm{c}-m y b$ combination. The demonstration that $\mathrm{c}-m y b$ can interact synergistically with an EBV-encoded transactivator to activate two different promoters suggests that c-myb is likely to interact in a similar fashion with as yet unidentified cellular transcription factors.

\section{MATERIALS AND METHODS}

Cell lines. The cell lines used were the EBV-negative T-cell line Jurkat, the EBV-positive Burkitt's lymphoma line Raji, the cervical epithelial cell line HeLa, and an EBVpositive epithelial cell line, NPC-KT (49), made by fusing an adenoidal carcinoma line with a nasopharyngeal carcinoma line. Lymphoid lines were maintained in RPMI 1640 medium supplemented with $10 \%$ fetal calf serum. Epithelial cells were maintained in Dulbecco modified Eagle medium $\mathrm{H}$ supplemented with $10 \%$ fetal calf serum.

DNA transfections. Plasmid DNA was purified through two sequential cesium chloride gradients. Transfection of DNA into both lymphoid and epithelial cell lines was accomplished by using electroporation (54). For each condition, $10^{7}$ cells were shocked at $1,500 \mathrm{~V}$, using the Zapper electroporation unit (Medical Electronics Shop, University of Wisconsin). Epithelial cells were harvested and resuspended in RPMI 1640 medium for electroporation.

EA-CAT plasmids. The EA-CAT constructs used in this study (some of which have been previously described [21]) are shown in Fig. 1. The parent construct, pEA-CAT, contains the promoter of the BMRF1 gene from sequences -331 to +1 (relative to the RNA start site) linked to the chloramphenicol acetyltransferase (CAT) gene. 5 ' deletions of EA-CAT (Fig. 1A) were made by cutting with various restriction enzymes, blunt ending, and religating. These mutants are named to reflect the promoter sequences (relative to the mRNA start site of BMRF1) contained within each construct. Plasmid pEA-BS-CAT (used for site-directed mutagenesis) contains the BMRF1 promoter sequences $(-331$ to +1$)$ linked to the CAT gene in the Stratagene m13 Bluescript SK+ phagemid vector (Fig. 1B). Site-directed mutants that remove the AP-1 site, another $\mathrm{Z}$ binding site (ZRE), or the potential c-Myb binding site were constructed from the pEA-BS-CAT plasmid as shown in Fig. $1 B$.

The E1B-EAD-CAT plasmid was made by ligating three copies of the 30-bp BMRF1 promoter sequence from 79801 to $79830(-69$ to -39 relative to the mRNA start site) directly upstream of the adenovirus E1B TATA box in the E1B-CAT construct (36) (a gift from Katherine Martin and Michael Green) between the $\mathrm{XbaI}$ and $P s t$ restriction sites.

EBV $Z$ transactivator plasmids. Two different $Z$ expression vectors were used in these experiments. Most experiments were performed with the pEBV-ZIE construct, which as previously described (21) contains the EBV genomic fragment encoding the $\mathrm{Z}$ gene product inserted into the pHD1013 vector under the control of the cytomegalovirus (CMV) IE promoter. In experiments using pEBV-ZIE, equal amounts of the pHD1013 vector (containing the CMV IE promoter but no $\mathrm{Z}$ gene) versus the EBV-ZIE plasmid were transfected in parallel to control for promoter competition effects.

Deletional analysis of the $\mathrm{Z}$ protein was performed by using a series of deletions derived from the parental vector, pKSV41. As previously described (16), the pKSV41 construct is a pUC18-based plasmid which contains the $\mathrm{Z}$ cDNA under the control of the SV40 early promoter and enhancer.

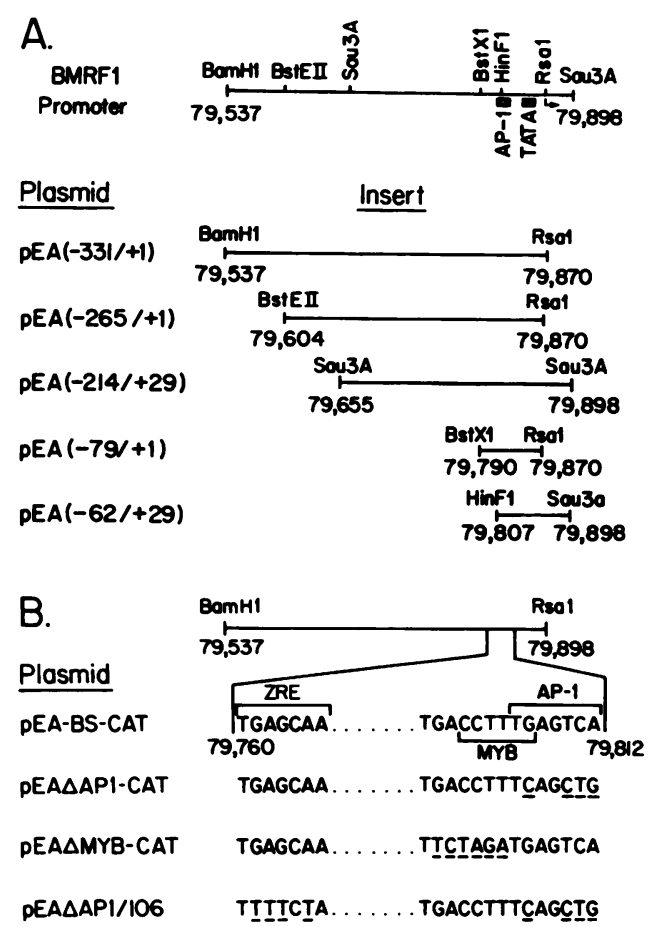

FIG. 1. (A) Construction of $5^{\prime}$ deletions of pEA-CAT. The parent pEA-CAT construct contains the EBV BamHI-RsaI fragment (EBV nucleotides 79537 to 79870) linked to CAT. A series of 5 ' deletion mutants was constructed by cutting at the indicated restriction endonuclease site, blunt ending with $\mathrm{T} 4$ polymerase or Klenow enzyme, and religating. The sites of the TATA box and potential AP-1 binding site are shown. (B) Construction of sitedirected mutations. The parent construct, pEA-BS-CAT, contains the EBV BamHI-RsaI fragment linked to CAT in a phagemid vector. The AP-1 site, an additional upstream $Z$ binding site (ZRE), and the potential $\mathrm{c}-\mathrm{Myb}$ binding site were abolished by using the Kunkel method (30) of site-directed mutagenesis as shown.

As shown in Fig. 2A, in-frame deletional mutants of $\mathrm{Z}$ were constructed by cutting at convenient restriction enzyme locations and religating. The mutants are named to reflect the location of the $\mathrm{Z}$ amino acids that were deleted. The stability and cellular localization of these mutants was tested by transfection of the mutated versus wild-type pKSV41 plasmids into COS-7 cells, separation of the nuclear and cytoplasmic fractions, sodium dodecyl sulfate-polyacrylamide gel electrophoresis, and immunoblotting. This analysis (which is presented in detail elsewhere [16]) indicated that two of the mutant proteins, produced from plasmids $\mathrm{Z} \Delta 42-191$ and $\mathrm{Z} \Delta 140-227$, were unstable, while the other mutant proteins were all as stable as the wild-type protein. Of the mutant proteins that were shown to be stable, all except $\mathrm{Z} \Delta 200-227$ were shown to have nuclear localization. Since all of the mutations shown in Fig. $2 \mathrm{~A}$ which involved the DNA binding domain of the $\mathrm{Z}$ protein either were found to be unstable or did not localize within the nucleus, we also tested a mutant containing a site-directed mutation within the DNA binding domain of $\mathrm{Z}$ (plasmid pZ311; Fig. 2B). The $\mathrm{Z} 311$ mutant produces $\mathrm{Z}$ protein which is stable and localizes to the nucleus, although the protein has completely lost DNA binding activity (16).

c-myb transactivator plasmids. The parental c-myb expression vector, pRmb3SVneo, which has been previously described (10), contains a mouse $c-m y b$ cDNA under the 


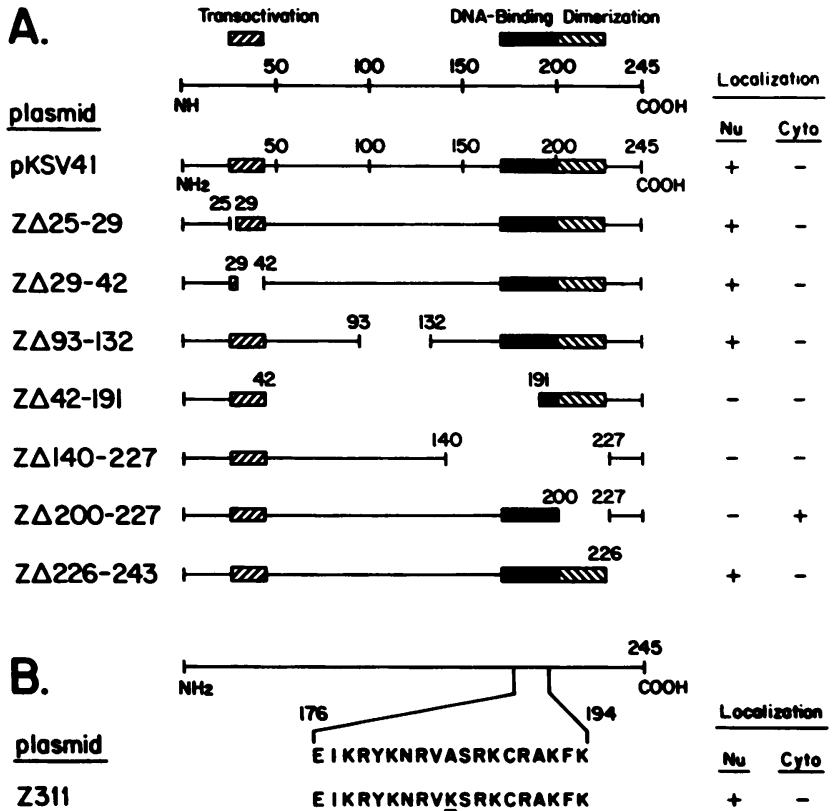

FIG. 2. (A) Construction of the EBV Z transactivator plasmids. The parent plasmid, pKSV41, contains the $\mathrm{Z}$ cDNA driven by the SV40 early promoter and enhancer in a pUC18-based plasmid as previously described (16). In-frame deletion mutants of pKSV41 were created by cutting with convenient restriction enzymes, blunt ending, and religating as shown. The mutants are named to reflect the position of the amino acids removed from the $\mathrm{Z}$ protein. The positions of the previously mapped transactivation domain, DNA binding domain, and dimerization domain within the $\mathrm{Z}$ protein are indicated. Nuclear $(\mathrm{Nu})$ versus cytoplasmic $(\mathrm{Cy})$ localization is indicated. (B) Construction of plasmid Z311. The Z311 plasmid contains a site-directed mutation in the DNA binding domain as shown. The resultant protein cannot bind DNA but is stable and localizes in the nucleus.

control of the Rous sarcoma virus long terminal repeat in addition to the neomycin resistance gene driven by the SV40 promoter. The vector pJTmyb-fs, which is identical to pRmb3SVneo except for a frameshift mutation within the $c-m y b$ coding sequence (10) (a gift from Jenny Ting), was used to control for vector effects in experiments using the pRmb3SVneo plasmid. Myb $\Delta 2 R$ was constructed by removing the first and second 51- to 52-amino-acid repeat elements (which contain the DNA binding domain of c-Myb) by the polymerase chain reaction technique and recloning the remainder of the $\mathrm{c}-m y b$ protein into the $\mathrm{pHD} 1013$ vector under the control of the CMV IE promoter. Potential CMV IE promoter competition effects were controlled for by including a transfection condition with the pHD1013 vector alone (without c-myb) as a control in all experiments using this construct.

CAT assays. Cells were transfected with $10 \mu \mathrm{g}$ of plasmid DNA, using the electroporation method. Forty-eight hours after transfection, a cell extract was prepared and incubated at $37^{\circ} \mathrm{C}$ with ${ }^{14} \mathrm{C}$-labelled chloramphenicol in the presence of acetyl coenzyme A as described previously (17). The percent acetylation of chloramphenicol was quantitated by thin-layer chromatography followed by autoradiography and scintillation counting. Some of the CAT assays shown in Fig. 3 and 8 are off-scale and thus represent potential underestimations of the actual $\mathrm{Z} / \mathrm{c}-m y b$ synergy. For the calculations shown in the tables and Fig. 9, CAT assays were repeated if results were not in the linear range (less than $80 \%$ chloramphenicol acetylation), using smaller amounts of extract.

Western immunoblots. To quantitate the level of $\mathrm{Z}$ protein expression in transfected cells, $10^{7}$ Jurkat cells were transfected as described above. The cells were harvested after 48 h (a portion was used for the CAT assay), washed with phosphate-buffered saline (PBS) twice, resuspended in 0.25 $M$ Tris (pH 8.0), lysed by freeze-thaw and sonication, and cleared by centrifugation. The soluble proteins were separated by electrophoresis through a $12.5 \%$ polyacrylamide gel and transferred electrophoretically to nitrocellulose. The preblocked nitrocellulose filter was incubated for $1 \mathrm{~h}$ at $37^{\circ} \mathrm{C}$ with a 1:100 dilution of pooled sera from patients with nasopharyngeal carcinoma (a gift from Pierre Buisson), followed by human anti-immunoglobulin G-peroxidase conjugate. The coloring agent was developed by incubation in 3,3'-diaminobenzidine and hydrogen peroxide.

RNA analysis. CAT mRNA was quantitated using S1 nuclease protection (12). Cytoplasmic RNA was prepared 24 $\mathrm{h}$ after transfection as previously described (15). A 20-bp oligonucleotide primer homologous to the CAT gene in the region 240 to 254 bp downstream of the ATG codon was synthesized and hybridized to single-stranded DNA produced from the EA-PBS-CAT phagemid construct. A complementary single-stranded uniformly labelled DNA probe was subsequently synthesized by extending the oligonucleotide with Klenow enzyme in the presence of ${ }^{32} \mathrm{P}$-labelled dCTP, cutting the DNA with XbaI (located directly upstream of the 332-bp BMRF1 promoter element), and isolating the resultant approximately 600 -bp single-stranded probe on a denaturing acrylamide gel. The probe was then hybridized overnight with cytoplasmic RNA in a solution containing $80 \%$ formamide, $40 \mathrm{mM}$ PIPES [piperazine- $N, N^{\prime}$-bis(2ethanesulfonic acid)], $400 \mathrm{mM} \mathrm{NaCl}$, and $1 \mathrm{mM}$ EDTA and digested with $\mathrm{S} 1$ nuclease, and the protected fragments were electrophoresed on a $6 \%$ acrylamide-7 $\mathrm{M}$ urea gel.

In vitro site-directed mutagenesis. Mutants were made by using the Bio-Rad Muta-Gene phagemid in vitro mutagenesis kit according to a method described by Kunkel (30). Mutants were made by using a synthetic oligonucleotide complementary to the region to be altered except for a limited internal mismatch. For screening possible mutants, synthetic oligonucleotides were designed to create new restriction sites. The AP-1 mutation has been previously described (21).

$\mathbf{Z}$ binding studies. The $\mathrm{Z}$ protein was in vitro transcribed and translated by using wheat germ lysate from the SP64 vector containing $\mathrm{Z}$ cDNA (44) (a gift from Paul Farrell). A ${ }^{32} \mathrm{P}$-end-labelled probe containing BMRF1 promoter sequences from -79 to +128 was incubated with $5 \mu$ l of in vitro-translated $\mathrm{Z}$ protein for $30 \mathrm{~min}$ at room temperature. Binding reactions were performed in buffer containing 100 $\mathrm{mM} \mathrm{KCl}, 20 \mathrm{mM}$ HEPES ( $N$-2-hydroxyethylpiperazine- $N^{\prime}-$ 2-ethanesulfonic acid; $\mathrm{pH} 7.3), 10 \%$ glycerol, $0.2 \mathrm{mM}$ EDTA, $4 \mathrm{mM}$ dithiothreitol, $5 \mathrm{mM}$ phenylmethylsulfonyl fluoride, and $2 \mu \mathrm{g}$ of poly $(\mathrm{dI}-\mathrm{dC}) \cdot \operatorname{poly}(\mathrm{dI}-\mathrm{dC})$. For methylation protection studies, dimethylsulfate $(1 \mu \mathrm{l})$ was added to the binding reaction immediately prior to loading onto a $5 \%$ polyacrylamide- $0.5 \%$ Tris-borate-EDTA gel. Two bands representing the bound probe and one band representing the free probe were cut from the gel and transferred to DEAE membrane paper. The membrane was incubated with $1 \mathrm{M}$ piperidine at $90^{\circ} \mathrm{C}$ for $30 \mathrm{~min}$ and then rinsed twice with sterile water. The probe fragments were then eluted by incubating the membrane with $1 \mathrm{M} \mathrm{NaCl}-0.1 \mathrm{mM}$ EDTA-20 $\mathrm{mM}$ Tris $(\mathrm{pH} 8.0)$ at $67^{\circ} \mathrm{C}$. Equal amounts of the radioactive 
bound and free probes were then analyzed on a $6 \%$ polyacrylamide-7 $\mathrm{M}$ urea gel.

Myb binding studies. Potential $m y b$ protein binding to the BMRF1 promoter was studied by using a bacterial fusion $\mathrm{v}-m y b$ protein (14) (a gift from J. Lipsick) which has been previously described (14). V-Myb binding to the BMRF1 promoter was analyzed by using a synthetic double-stranded oligonucleotide sequence (oligonucleotide EAD) containing the BMRF1 promoter sequences from -50 to -83 relative to the mRNA start site flanked by EcoRI and Sall restriction sites (ATGTCGACGAATTCGCTGGTGGTAGATGACCT TTGAGTCAGGGTGGCTGTCGACACA). Oligonucleotide sequences containing mutations in the AP-1 site (EAD AP-1; ATGTCGACGAATTCGCTGGTGGTAGATGACCTTTC AGCTGGGGTGGCTGTCGACACA) or the potential c-myb site (EAD MYB; ATGTCGACGAATTCGCTGGTGGTAG ATTCTAGATGAGTCAGGGTGGCTGTCGACACA) were also analyzed. An oligonucleotide containing four copies of a consensus c-Myb binding site (CAGTTA) was also constructed (MYB; CCGAATTCCAGTTAATAGCAG TTAATAGCAGTTAATAGCAGTTAATTT) to use as a positive control for Myb binding. Gel mobility shift assays were performed by incubating the renatured, double-stranded synthetic oligonucleotides (after end labelling with ${ }^{32} \mathrm{P}$ by Klenow reaction) with protein extracts from the bacteria producing $v-m y b$ protein (T7MYB) or protein extracts from bacteria containing the negative control vector (MYBLESS) in a reaction buffer containing $10 \mathrm{mM}$ Tris- $\mathrm{HCl}(\mathrm{pH} 7.5), 50$ $\mathrm{mM} \mathrm{NaCl}, 1 \mathrm{mM}$ dithiothreitol, $1 \mathrm{mM}$ EDTA, 5\% glycerol, and $80 \mu \mathrm{g}$ of poly $(\mathrm{dI}-\mathrm{dC}) \cdot($ poly $(\mathrm{dI}-\mathrm{dC})$ per $\mathrm{ml}$ for $30 \mathrm{~min}$ at $4^{\circ} \mathrm{C}$. Free and bound complexes were then resolved by electrophoresis in a polyacrylamide gel in $0.5 \times$ Tris-borateEDTA buffer at $40 \mathrm{~V} \mathrm{~cm}^{-1}$ for $30 \mathrm{~min}$ at $4^{\circ} \mathrm{C}$ and subjected to autoradiography. The effect of anti-myb antibody on bound complexes was determined by comparing the results of mixing $1 \mu \mathrm{l}$ of preimmune rabbit serum versus $1 \mu \mathrm{l}$ of rabbit polyclonal anti-try-myb 2 serum (3) (a gift from J. Lipsick) into the reaction mixture $30 \mathrm{~min}$ before adding the labelled probe.

\section{RESULTS}

The EBV BMRF1 promoter and the SV40 early promoter are synergistically activated by the combination of $Z$ and c-myb in lymphoid cells. We first examined the ability of the $c-m y b$ oncogene to complement the $\mathrm{Z}$ gene product in transient cotransfection assays in which the BMRF1 early EBV promoter was linked to the heterologous CAT gene. Figure 3 shows the results of representative CAT assays. In the Jurkat T-cell line (Fig. 3A), the activity of the BMRF1 promoter (linked to CAT) was only slightly increased by cotransfection with $\mathrm{Z}$ alone (one- to eightfold increase in multiple experiments) or by cotransfection with c-myb alone (one- to sevenfold increase). Most striking was the effect of $\mathrm{Z}$ and c-myb together in this cell type, producing increases in EA-CAT activity from 25 - to 150 -fold in different experiments. In the EBV-positive B-cell line Raji (Fig. 3B), the effect of $Z$ alone is more efficient, since $Z$ activates the expression of another EBV-encoded transactivator, BRLF1, and we have previously shown that $\mathrm{Z}$ and BRLF1 interact synergistically to activate the BMRF1 promoter in lymphoid cells (21). Nevertheless, the addition of $c-m y b$ to $Z$ in Raji cells consistently results in approximately fourfold-higher levels of BMRF1 promoter activation than seen with $Z$ alone, even though the c-myb transactivator by itself has little, if any, effect on BMRF1 promoter activity in this cell

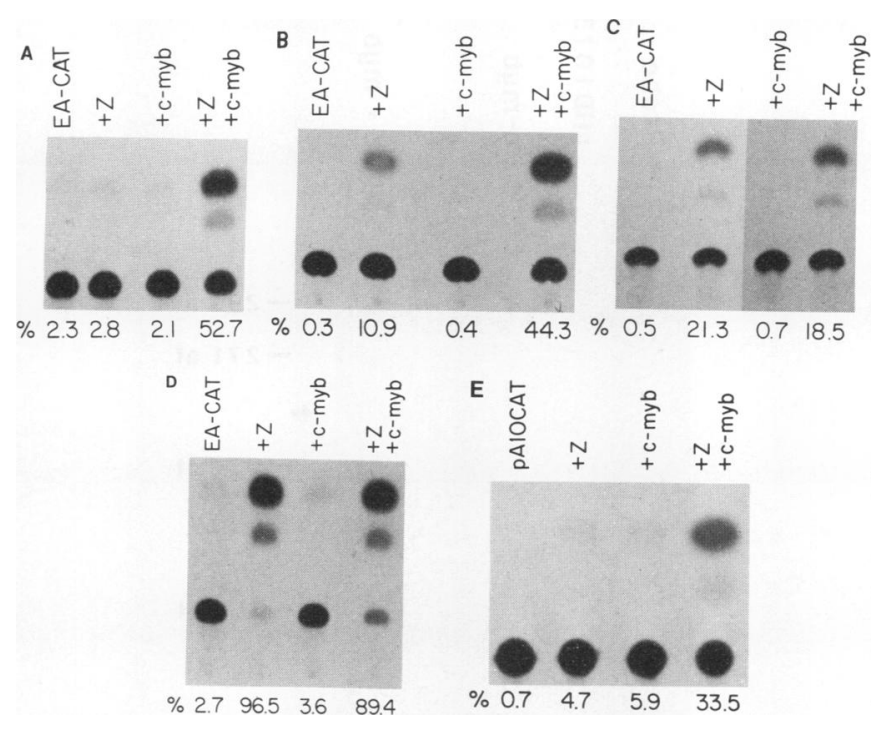

FIG. 3. Evidence that the EBV Z transactivator/c-myb combination synergistically activates the EBV BMRF1 and SV40 early promoters. The BMRF1 promoter-CAT construct (EAD-CAT) was transfected into the Jurkat T-cell line (A), the EBV-positive Burkitt's lymphoma cell line Raji (B), HeLa cells (C), or the EBVpositive epithelial cell line NPC-KT (D). The EAD-CAT plasmid was cotransfected with either vector control DNA, the $Z$ transactivator alone, the c-myb transactivator alone, or the $\mathrm{Z}$ and c-myb transactivators together. In Jurkat and Raji cells, the combination of $\mathrm{Z}$ and c-myb is synergistic, whereas in HeLa and NPC-KT cells, Z alone is as effective as $\mathrm{Z}$ and c-myb together. The SV40 early promoter (pA10CAT) (31) is also synergistically activated in Jurkat cells by the combination of $\mathrm{Z}$ and c-myb (E).

type. However, the combination of $\mathrm{Z}$ and $\mathrm{c}-m y b$ was no more effective than $\mathrm{Z}$ alone in two different epithelial lines, the EBV-negative HeLa cell line (Fig. 3C) and the EBVpositive NPC-KT cell line (Fig. 3D). In these cell lines, $\mathrm{Z}$ by itself efficiently transactivates the BMRF1 promoter.

The SV40 early promoter (pA10CAT construct) (31), which contains an AP-1 binding site, was also synergistically activated by the combination of $\mathrm{Z}$ and c-myb in Jurkat cells (Fig. 3E). However, c-myb did not affect the activity of the EBV BMLF1 promoter (with or without Z) (data not shown), although this promoter contains an AP-1 site which has previously been shown to bind the $\mathrm{Z}$ protein (11).

BMRF1-driven CAT RNA is increased by the Z/c-myb combination. In previous studies, we have mapped the RNA start site of the BMRF1 promoter to EBV sequence 79869 (approximately $25 \mathrm{bp}$ downstream of a potential TATA box element) and shown that the RNA start site is not altered in the presence of the $\mathrm{Z}$ transactivator (21). In this study, we used $S 1$ nuclease analysis to examine the effect of the $\mathrm{Z} / \mathrm{c}-m y b$ combination on the steady-state level of EA-CAT RNA. In the experiment shown in Fig. 4, $5 \mu \mathrm{g}$ of the EA-CAT construct was cotransfected with $5 \mu \mathrm{g}$ of either vector DNA alone (pHD1013), the c-myb construct alone, the EBV-ZIE construct (a vector which contains the $\mathrm{Z}$ gene product in plasmid pHD1013 driven by the CMV IE promoter [21]) alone, or the combination of $c-m y b$ and $Z$. Cytoplasmic RNA was harvested $24 \mathrm{~h}$ after transfection, hybridized to a uniformly ${ }^{32} \mathrm{P}$-labelled single-stranded DNA probe homologous to the EA-CAT gene sequences extending from $254 \mathrm{bp}$ downstream of the CAT ATG codon to 331 bp upstream of the presumed RNA start site, and digested 


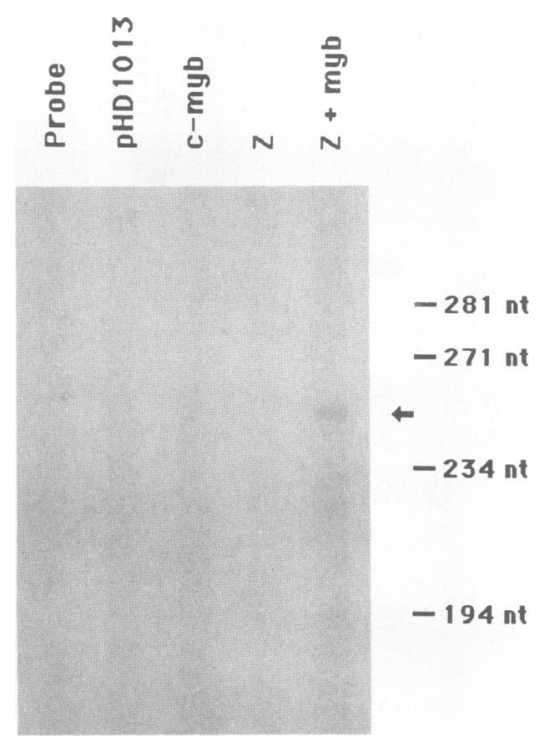

FIG. 4. Effect of the $\mathrm{Z} / \mathrm{c}-m y b$ transactivator combination on steady-state CAT mRNA level. The BMRF1 promoter-CAT construct (EAD-CAT) was transfected into Jurkat cells with either control vector DNA, the $\mathrm{Z}$ transactivator alone, the c-myb transactivator alone, or the combination of both transactivators. Cytoplasmic RNA was harvested $24 \mathrm{~h}$ after transfection, hybridized with a complementary ${ }^{32} \mathrm{P}$-labelled single-stranded DNA probe extending from $331 \mathrm{bp}$ upstream of the expected RNA start site to $254 \mathrm{bp}$ downstream of the CAT ATG codon, and digested with S1 nuclease. The combination of the $\mathrm{Z}$ and c-myb transactivators significantly increased the level of EAD-CAT mRNA. nt, nucleotides.

with $\mathrm{S} 1$ nuclease. In cells transfected with the $\mathrm{Z} / \mathrm{c}-m y b$ combination, an S1-protected fragment of the expected size (approximately $260 \mathrm{bp}$ ) is observed; moreover, the level of EA-CAT mRNA is clearly increased.

Localization of the BMRF1 promoter regions required for response to the $\mathrm{Z} / \mathrm{c}-\mathrm{myb}$ combination. To define the region(s) of the BMRF1 promoter that is required for maximal responsiveness to the $\mathrm{Z} / \mathrm{c}-m y b$ transactivator combination, we constructed a series of $5^{\prime}$ deletions of the BMRF1 promoter (linked to CAT) as previously described (21) and tested the ability of each construct to respond to $\mathrm{Z}$ alone or to the combination of $\mathrm{Z}$ plus c-myb in lymphoid cells (Table 1 ).

In this set of experiments, the parent construct, which contains BMRF1 promoter sequences from -331 to +1

TABLE 1. Effects of the $\mathrm{Z}$ transactivator alone and of the $\mathrm{Z} / \mathrm{c}-m y b$ combination on $\mathrm{pEA}-\mathrm{CAT}$ deletion plasmids in Jurkat cells

\begin{tabular}{lrcrrr}
\hline \multirow{2}{*}{ Plasmid } & \multicolumn{3}{c}{ Fold increase in CAT activity } \\
\cline { 2 - 3 } & \multicolumn{2}{c}{ Z transactivator } & & \multicolumn{2}{c}{ Z/c-myb } \\
\cline { 2 - 3 } \cline { 5 - 6 } & Avg & Range & & Avg & Range \\
\hline pEA-CAT(-331/+1) & 2.3 & $2.1-2.4$ & & 92.8 & $47.6-137.9$ \\
pEA-CAT(-265/+1) & 11.9 & $4.0-19.7$ & & 152.5 & $152.1-152.8$ \\
pEA-CAT(-214/+29) & 3.4 & $2.5-4.2$ & & 37.3 & $14.5-50.0$ \\
pEA-CAT(-79/+1) & 1.5 & $0.5-2.4$ & & 32.3 & $30.2-34.3$ \\
pEA-CAT(-62/+29) & 0.7 & $0.7-0.7$ & & 2.2 & $1.7-2.6$ \\
\hline
\end{tabular}

${ }^{a}$ Values represent the average fold increase in CAT activity when each CAT plasmid was cotransfected with the $\mathrm{Z}$ transactivator alone ( $\mathrm{pEBV}$-ZIE) or with the combination of $\mathrm{Z}$ and $c-m y b$. Ranges are those seen in two experiments. relative to the RNA start site, was transactivated an average of 93 -fold by the combination of $\mathrm{Z}$ and $c-m y b$, versus only 2.3-fold by $\mathrm{Z}$ alone in the same set of experiments. The effect of the $\mathrm{Z}$ transactivator alone (as was observed previously [21]) could be significantly increased by deleting the sequences between -331 and -265 , although even with this construct the effect of $\mathrm{Z}$ and c-myb together was still much greater than that of $\mathrm{Z}$ alone (152-fold transactivation versus 12-fold). A significant loss in the response of the promoter to the $\mathrm{Z} / \mathrm{c}-m y b$ combination occurred when the sequences between -265 and -214 were deleted, although a substantial transactivation effect still remained (37-fold transactivation). The most precipitous drop in transactivation with the $\mathrm{Z} / \mathrm{c}$ myb combination occurred when the sequences between -79 and -62 were deleted, with transactivation decreasing from 32 -fold to only 2 -fold as these sequences were removed. Thus, the sequences between -62 and -79 appear to be most important for response of the EAD promoter to the $\mathrm{Z} / \mathrm{c}-\mathrm{myb}$ combination.

The $Z$ protein binds to the AP-1 site in the BMRF1 promoter. Although the BMRF1 promoter contains a consensus AP-1 binding site, the binding of $\mathrm{Z}$ protein to this promoter has not been previously studied. We used in vitro-transcribed and -translated $\mathrm{Z}$ protein to study $\mathrm{Z}$ binding to the BMRF1 promoter. In gel retardation assays (Fig. 5A), in vitro-translated $\mathrm{Z}$ protein produced retarded bands when incubated with a ${ }^{32} \mathrm{P}$-labelled probe encompassing the BMRF1 promoter sequences from -79 to +128 (relative to the mRNA start site). $\mathrm{Z}$ binding to this probe was specifically competed for by cold competitor oligonucleotide DNA (EAD) encompassing the BMRF1 promoter sequences from -50 to -83 (which contains the AP-1 site) but not by competitor DNA ( $\triangle \mathrm{AP}-1)$ in which the AP-1 site in the BMRF1 sequence had been mutated. Competitor DNA $(\triangle M Y B)$ in which the potential c-Myb binding site had been mutated competed for $\mathrm{Z}$ binding with the same affinity as did the wild-type sequence. Methylation protection studies of the bound DNA fragments confirmed that the $\mathrm{Z}$ protein, as expected, binds to the AP-1 site in the BMRF1 promoter (Fig. 5B). $\mathrm{Z}$ also binds to one other site in the BMRF1 promoter (a ZRE site) located at position -106 relative to the mRNA start site (43a).

Roles of the BMRF1 promoter AP-1 site and a potential c-Myb binding site in the $\mathrm{Z} / \mathrm{c}-\mathrm{myb}$ transactivation response. The 5' deletional analysis of the BMRF1 promoter suggested that sequences located between -62 and -79 were required for maximum response to the $\mathrm{Z} / \mathrm{c}-m y b$ combination. Examination of the BMRF1 promoter sequence from -62 to -79 (Fig. 1B) reveals that it contains a consensus AP-1 site, TGAGTCA. In addition, overlapping the AP-1 site is the sequence CCTTTG, which is a 1-bp mismatch from the consensus c-Myb binding sequence $(\mathrm{C} / \mathrm{T}) \mathrm{AAC}(\mathrm{G} / \mathrm{T}) \mathrm{G}$, or $\mathrm{C}(\mathrm{A} / \underline{\mathrm{C}}) \mathrm{GTT}(\mathrm{A} / \underline{\mathrm{G}})$ when read on the opposite strand $5^{\prime}$ to $3^{\prime}$. Further upstream $(-106$ relative the mRNA start site) is another $\mathrm{Z}$ binding site (43a) homologous to previously reported ZREs $(4,11,13,29,35,43,45,50,55)$.

To determine whether the AP-1 site, the ZRE, or the potential c-Myb binding site contributes to transactivation of the BMRF1 promoter by the Z/c-myb combination, we made site-directed mutations which specifically abolished either the AP-1 site alone, the AP-1 site and the ZRE simultaneously, or the potential c-Myb binding site. We then tested these mutated promoter constructs for the ability to respond to $\mathrm{Z}$ alone, c-myb alone, or the combination of $\mathrm{Z}$ and c-myb (Table 2).

In this set of experiments, the average fold increase in 


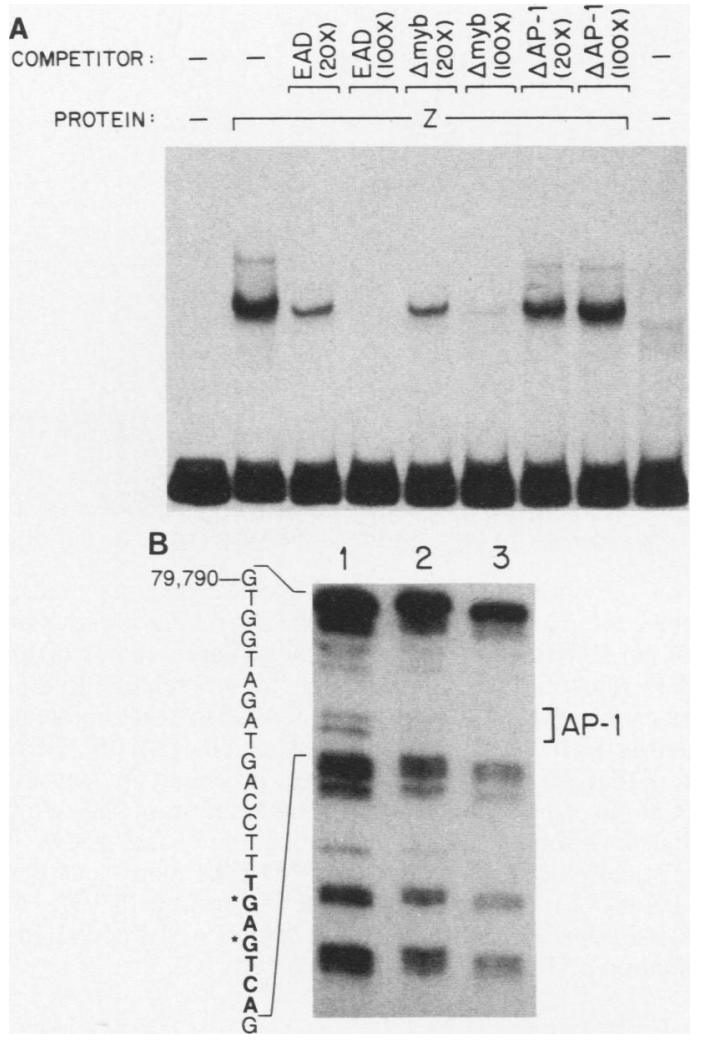

FIG. 5. Binding of the $Z$ protein to the AP-1 site in the BMRF1 promoter. (A) In vitro-transcribed and -translated $Z$ protein was incubated with $\mathrm{a}^{32} \mathrm{P}$-labelled probe containing the BMRF1 promoter sequences from -79 to +126 (relative to the mRNA start site) at $23^{\circ} \mathrm{C}$ for $30 \mathrm{~min}$, and then the products were resolved by gel electrophoresis and autoradiography. The in vitro-translated $\mathrm{Z}$ protein produced retarded complexes with the BMRF1 promoter probe that were not seen with the untranslated wheat germ extract alone (last lane). Competition studies showed that cold competitor DNA (at 20- and 100-fold molar excess) containing the BMRF1 promoter sequences from -50 to -83 (oligonucleotide EAD) specifically competed for $\mathrm{Z}$ binding. Cold competitor DNA containing the same BMRF1 sequences but with the AP-1 site abolished (oligonucleotide $\triangle \mathrm{AP}-1$ ) did not compete. Competitor DNA which abolished the potential c-Myb binding site (oligonucleotide $\triangle M Y B$ ) competed for $Z$ binding with the same efficiency as did the wild-type sequence. (B) A ${ }^{32}$ P-end-labelled probe containing the BMRF1 promoter sequences from -79 to +126 was incubated with in vitro-translated $\mathrm{Z}$ protein and then treated with dimethylsulfate immediately prior to gel electrophoresis. Two different retarded gel complexes (lanes 2 and 3, with lane 3 having the most retarded complex) and the free probe (lane 1) were removed separately, cut with piperidine, and then analyzed on a $6 \%$ polyacrylamide-urea gel. The position of the AP-1 binding site is as shown. Binding by $Z$ to the BMRF1 probe appears to protect the BMRF1 probe from methylation.

EA-CAT activity induced by $\mathrm{Z}$ alone in Jurkat cells was 3.8, the average fold increase induced by c-myb alone was 2.5 , and the average fold increase induced by both transactivators together was 32.3. When the AP-1 site was abolished by site-directed mutation, the effect of $Z$ alone decreased significantly (down to 0.9), as did the effect of $\mathrm{Z}$ and c-myb together (down from 32.3 to 8.5). The residual 8.5-fold effect of the $\mathrm{Z} / \mathrm{c}-m y b$ combination on this mutant was essentially lost when the upstream ZRE was also destroyed (down to 2.4-fold effect). Therefore, it appears that at least one $\mathrm{Z}$
TABLE 2. Effects of the $\mathrm{Z}$ transactivator, the c-myb transactivator, and the $\mathrm{Z} / \mathrm{c}-\mathrm{my} \boldsymbol{b}$ combination on pEA-BS-CAT site-directed mutants in Jurkat cells

\begin{tabular}{|c|c|c|c|c|c|c|}
\hline \multirow{3}{*}{ Plasmid } & \multicolumn{6}{|c|}{ Fold increase in CAT activity ${ }^{a}$} \\
\hline & \multicolumn{2}{|c|}{$\mathrm{Z}$ alone } & \multicolumn{2}{|c|}{ c-myb alone } & \multicolumn{2}{|c|}{$\mathrm{Z} / \mathrm{C}-m y b$} \\
\hline & Avg & Range & Avg & Range & Avg & Range \\
\hline pEA-BS-CAT & 3.8 & $1.2-5.8$ & 2.5 & $0.9-3.5$ & 32.3 & $22.6-39.8$ \\
\hline pEA $\triangle A$ P-1-CAT & 0.9 & $0.6-1.2$ & 1.7 & $1.1-2.2$ & 8.5 & $4.5-15.9$ \\
\hline pEA $\Delta$ AP-1/106 & 0.3 & $0.1-0.7$ & 1.7 & $0.4-2.8$ & 2.4 & $1.8-6.0$ \\
\hline pEA $\triangle M Y B-C A T$ & 12.9 & $6.9-23.5$ & 3.2 & $1.7-4.6$ & 40.2 & $22.8-61.1$ \\
\hline
\end{tabular}

" Values represent the average fold increase in CAT activity when each CAT plasmid was cotransfected with either $\mathrm{Z}$ alone, c-myb alone, or the combination of both transactivators. Ranges are those seen in three experiments.

binding site is required for the synergistic $\mathrm{Z} / \mathrm{c}-\mathrm{my} b$ transactivation effect.

When the potential c-Myb binding site was abolished by site-directed mutation, the effect of both transactivators together was not diminished, nor was the effect of c-myb alone. Therefore, it seems unlikely that the $\mathrm{Z} / \mathrm{c}-m y b$ synergy is mediated through binding of $\mathrm{c}-\mathrm{Myb}$ to this site. In fact, it would be somewhat surprising if c-Myb were to bind to this site, since the substitution of $C$ to $A$ in the fourth position of the consensus Myb binding site (PyAACG/TG) has been previously shown to inhibit binding by v-Myb (23). However, the effect of $\mathrm{Z}$ alone in Jurkat cells was unexpectedly somewhat increased (from 3.8- to 12.9-fold).

v-myb protein does not bind to the BMRF1 promoter. Although site-directed mutagenesis of the CCTTTG sequence suggested that this sequence itself is not required for $\mathrm{Z} / \mathrm{c}-m y b$ activation of the BMRF1 promoter, c-Myb could potentially bind elsewhere in the promoter, using a novel binding site. Since the bihding affinities of the c-myb and $v-m y b$ proteins are thought to be essentially identical, we used a bacterial vector expressing a $v-m y b$ fusion protein (a gift from J. Lipsick), T7MYB (14), to study potential myb protein binding to the BMRF1 promoter. Using this fusion protein, we routinely observed strong binding to a control probe containing four copies of the consensus Myb binding site (Fig. 6). As expected, binding by $\mathrm{v}-\mathrm{Myb}$ was inhibited by a 20-fold molar excess of competitor DNA containing the consensus c-Myb binding site. However, two different oligonucleotides containing the potential Myb binding site in the BMRF1 promoter (oligonucleotides EAD and EAD AP-1) were unable to compete for $\mathrm{v}$-Myb binding, even at a 300-fold molar excess. Likewise, a ${ }^{32}$ P-labelled probe containing the potential Myb binding site in the BMRF1 promoter did not bind the $v-m y b$ protein (data not shown). Therefore, it appears unlikely that $\mathrm{c}-\mathrm{Myb}$ can bind to the BMRF1 promoter independently. However, since c-Myb binding may be stabilized by cellular factors, we cannot totally exclude the possibility that $\mathrm{c}-\mathrm{Myb}$ may bind to the BMRF1 promoter in vivo.

A 30-bp BMRF1 promoter sequence is sufficient to transfer $\mathrm{Z} / \mathbf{c}-\mathbf{m y b}$ responsiveness to a heterologous promoter. To determine whether the BMRF1 promoter sequences containing the AP-1 binding site are sufficient to confer $\mathrm{Z} / \mathrm{c}-\mathrm{my} b$ responsiveness to a heterologous promoter, we inserted three copies of the 30-bp BMRF1 sequence (ACCTTTGAGTC AGGGTGGCTACTTGCTCAG) located from -39 to -69 (relative to the mRNA start site) upstream of the adenovirus E1B TATA box in the E1B-CAT plasmid (a gift from 


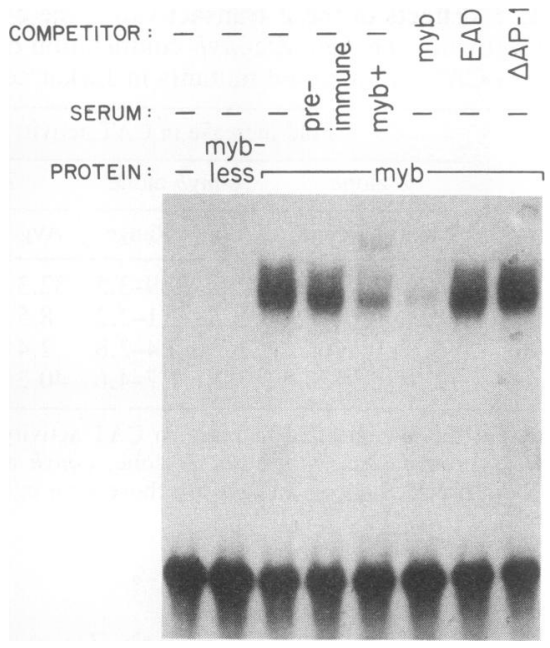

FIG. 6. Evidence that v-myb protein expressed in Escherichia coli does not bind to the BMRF1 promoter. Bacterial v-myb was expressed at high level in isopropyl- $\beta$-D-thiogalactopyranoside (IPTG)-induced $E$. coli bearing the pT7MYB vector (a gift from J. Lipsick) as previously described (14). Equal amounts of protein from bacterial extracts containing the pT7MYB vector or from the negative control vector pT7MYBLESS were incubated at $4^{\circ} \mathrm{C}$ for 30 min with a ${ }^{32} \mathrm{P}$-labelled oligonucleotide probe containing four copies of the consensus Myb binding site. The products were then resolved by nondenaturing gel electrophoresis and autoradiography. v-myb protein was shown to bind to the consensus c-Myb binding site as expected. Competition studies confirmed that a 20 -fold molar excess of cold oligonucleotide containing the consensus c-Myb binding site (oligonucleotide MYB) competed for binding to the labelled $m y b$ probe, whereas a 300 -fold excess of two different oligonucleotides (EAD and AP-1) containing the potential c-Myb binding site in the BMRF1 promoter did not compete. The $m y b$-specific antibody (3), as expected, decreased $\mathrm{v}-\mathrm{Myb}$ binding to the MYB probe, whereas preimmune serum had no effect. A labelled probe containing the potential $\mathrm{c}-\mathrm{Myb}$ binding site in the BMRF1 promoter did not bind the $v-m y b$ protein (data not shown).

Michael Green and Katherine Martin). As shown in Fig. 7, the -39 to -69 region of the BMRF1 promoter (which contains the AP-1 binding site but not the upstream ZRE binding site) is sufficient to transfer high-level responsiveness to the Z/c-myb combination. Furthermore, the transferred responsiveness to $\mathrm{Z} / \mathrm{c}-m y b$ continues to be lymphoid specific, in that it is observed in Jurkat cells but not in HeLa cells.

c-myb does not increase the level of transfected $Z$ protein. One mechanism by which the c-myb and $\mathrm{Z}$ transactivator plasmids might interact synergistically would be through the ability of transfected c-myb to increase the level of transfected $\mathrm{Z}$ protein. To exclude this possibility, we performed an experiment in Jurkat cells in which the level of $\mathrm{Z}$ expression in the presence and absence of c-myb was determined in a portion of the cell extract, and the level of BMRF1-CAT activity was simultaneously determined in the same protein extracts. As expected, the level of BMRF1driven CAT activity is much higher in the presence of $\mathrm{Z}$ and c-myb together than with $\mathrm{Z}$ alone (Fig. 8B). Furthermore, the level of transfected $\mathrm{Z}$ (determined by immunoblotting) is similar in each condition (Fig. 8A), excluding the possibility that the increased CAT activity in the Z/c-myb condition is due to increased $Z$ expression or differences in transfection efficiency. In addition, we found that the level of transfected $\mathrm{Z}$ tended to be consistently higher in Jurkat cells than in

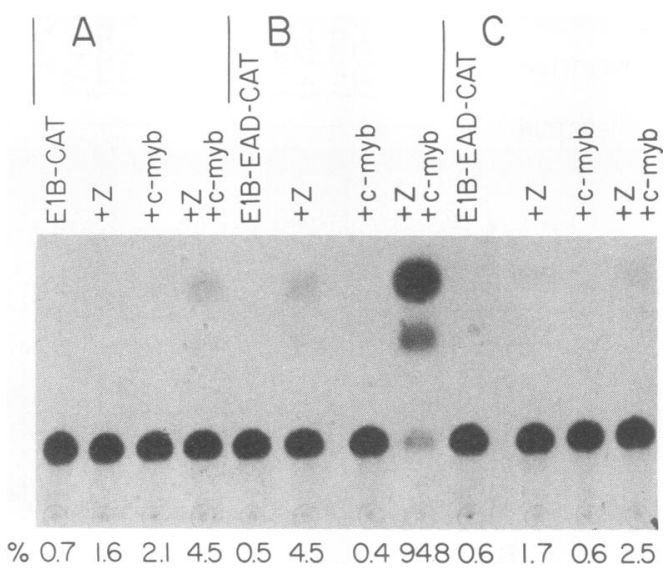

FIG. 7. Evidence that lymphoid-specific responsiveness to the $\mathrm{Z} / \mathrm{c}-m y b$ combination can be transferred to a heterologous promote by a 30-bp BMRF1 promoter sequence. Three copies of the 30-bp BMRF1 promoter sequence from -39 to -69 relative to the mRNA start site were inserted into the E1B-CAT construct upstream of the adenovirus E1B TATA box. In Jurkat cells (A), the parent construct, E1B-CAT, is not significantly activated by cotransfection with $\mathrm{Z}$ alone, c- $m y b$ alone, or the combination of the two transactivators. In contrast, the combination of $\mathrm{Z}$ and $\mathrm{c}-m y b$ together synergistically activates the E1B-EAD-CAT construct containing three copies of the BMRF1 AP-1 site in Jurkat cells (B). However, the E1B-EAD-CAT plasmid is not significantly activated by the combination of $\mathrm{Z}$ and c-myb in HeLa cells (C).

HeLa cells (data not shown), further ruling out the possibility that inefficient $\mathrm{Z}$ transactivation in Jurkat cells is simply due to insufficient expression of the $\mathrm{Z}$ transactivator in this cell type.

Defining domains in the $Z$ protein required for synergy with c-myb. To determine which portions of the $\mathrm{Z}$ protein are required for transactivation of the EA-CAT plasmid in cooperation with c-myb, we tested a series of in-frame deletion mutants of the $\mathrm{Z}$ protein for the ability to activate EA-CAT activity with and without the c-myb protein (Fig. 9). The parental construct used in these experiments contains the BZLF1 cDNA driven by the SV40 promoter (16). A number of in-frame deletions were constructed (Fig. 2A) which delete portions of the protein important for transactivation, DNA binding, or dimerization $(4,11,16)$. The

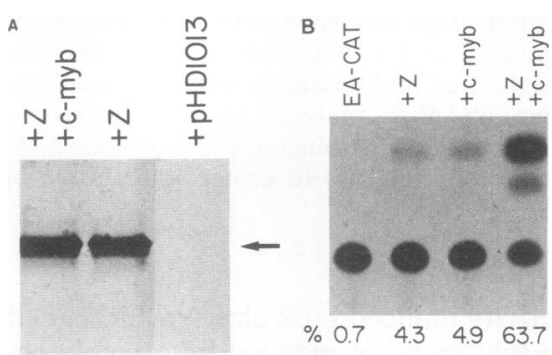

FIG. 8. Evidence that c-myb does not increase the level of transfected $\mathrm{Z}$ protein. To exclude the possibility that c-myb increases the level of transfected $\mathrm{Z}$ protein, immunoblotting was performed (using sera from patients with nasopharyngeal carcinoma) in Jurkat cells on a portion of the protein extract simultaneously harvested for CAT activity. The level of $Z$ protein is similar when $\mathrm{Z}$ is transfected alone or with c-myb (A), whereas the EAD-CAT activity is much higher in the cells transfected with both $\mathrm{Z}$ and $\mathrm{c}-m y b(\mathrm{~B})$. 


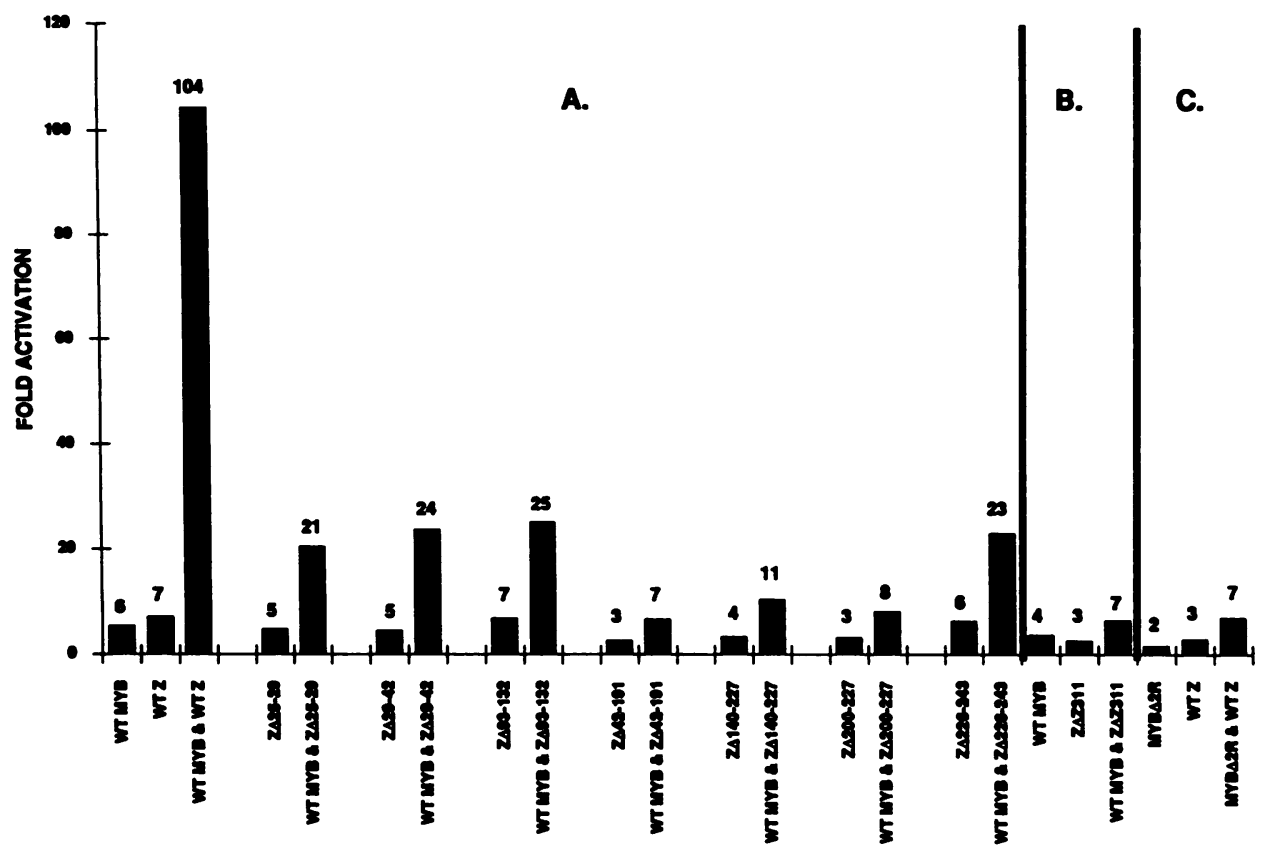

FIG. 9. Effects of $\mathrm{Z}$ and $c-m y b$ protein deletions on synergistic activation of the BMRF1 promoter. The EAD-CAT construct was cotransfected into Jurkat cells with either the pHD1013 vector alone, the wild-type $Z$ transactivator (WT Z) or the various $Z$ deletion mutants (Fig. 2), the wild-type c-myb protein (WT MYB), or a mutant c-myb protein in which the first two 51- to 52-amino-acid repeats had been deleted. The fold activation of EAD-CAT activity produced by the various combination of wild-type and mutant proteins is shown. (A) EAD-CAT plasmid cotransfected with wild-type $Z$ (either alone or in combination with wild-type c-myb) versus various $Z$ deletion mutants (an average of four separate experiments). (B) EAD-CAT plasmid cotransfected with wild-type Z (either alone or in combination with wild-type c- $m y b$ ) versus the Z311 site-directed mutant (an average value from three experiments). (C) EAD-CAT plasmid cotransfected with mutant c-myb with and without wild-type $\mathrm{Z}$ (an average from two experiments).

cellular localization of each mutant protein is shown in Fig. 2A.

In the first set of experiments (Fig. 9A), the average effect of wild-type $Z$ alone was 7 -fold, the average effect of wild-type c-myb alone was 6-fold, and the average effect of wild-type $\mathrm{Z}$ and wild-type c-myb together was 104-fold. Deletions which abolished the ability of $\mathrm{Z}$ to bind in vitro (either through deletion of the DNA binding domain or through deletion of the dimerization domain) all essentially abolished the ability of $\mathrm{Z}$ to interact synergistically with c- $m y b$ in activating EA-CAT expression. However, all of the deletions shown in Fig. 9A which affected DNA binding also were subsequently determined to affect protein stability or nuclear localization. Therefore, we confirmed the importance of the Z DNA binding function for synergy with c-myb by testing the Z311 plasmid, which contains a site-directed mutation in $\mathrm{Z}$ which abolishes DNA binding capacity but does not affect protein stability or nuclear localization (Fig. 9B). The Z311 mutant did not interact synergistically with $c-m y b$, confirming the importance of Z DNA binding function for this interaction. Deletions which affect the transactivation domain of $\mathrm{Z}$ also significantly decreased the combined effect of $\mathrm{Z}$ and $c-m y b$, although in each case the combined effect was still slightly greater than the additive effect of each transactivator alone (Fig. 9A). These results suggest that both the transactivation domain and the DNA binding domain of $\mathrm{Z}$ are important for cooperation with c-myb.

The DNA binding domain of c-Myb is also important for synergy with $Z$. The DNA binding domain of c-Myb has been previously localized to the amino-terminal portion of the protein $(14,22,28)$. The c-myb DNA binding domain is contained within a set of three imperfect 51- to 52-aminoacid repeats $(22,28)$. Although the first repeat does not appear to be essential for binding to the consensus c-myb response element, the second and third repeats do appear to be required for binding (22). Previous investigators have shown that transactivation of the heat shock promoter by $c-m y b$, which does not appear to involve a DNA binding mechanism, is still efficient even when the first and second repeats are deleted together (27). In contrast, transactivation of promoters linked to the consensus c-myb response element, which does require c-Myb binding, is negligible if the first and second repeats together are deleted (27).

We constructed a deletion of c-Myb that specifically removed the first and second 51- to 52-amino-acid repeats and tested this construct for the ability to transactivate the BMRF1 promoter in conjunction with $\mathrm{Z}$. Previous investigators have shown that deletion of the first and second repeats does not reduce protein stability or impair nuclear localization of the $c-m y b$ protein $(22,27)$ (although there is some evidence that the equivalent region may be required for v-myb nuclear localization in avian erythroid cells [23]). As shown in Fig. 9C, removal of the first and second repeats from the amino-terminal end of the c-myb protein essentially abolished the ability of c-myb to interact synergistically with $Z$. This finding suggests that the DNA binding function of $\mathrm{c}-\mathrm{Myb}$ is required for the observed $\mathrm{Z} / \mathrm{c}-m y b$ interaction. However, since we have not yet confirmed that this mutant stably localizes to the nucleus in Jurkat cells, we cannot totally exclude the possibility that the lack of synergy with this mutant is secondary to the inability of this mutant to localize in the nucleus. 


\section{DISCUSSION}

The EBV transactivating protein $\mathrm{Z}$ plays a key role in the disruption of viral latency. The $Z$ protein binds to AP-1 sites as a homodimer and (despite its sequence similarity with c-Fos) is not capable of heterodimerizing with either c-Fos or c-Jun (4). However, our data (21) demonstrate tissue specificity in the ability of certain promoters to respond to $\mathrm{Z}$, suggesting that $\mathrm{Z}$ transactivation of these promoters is likely to involve additional cellular transcription factors. In this paper, we report the first evidence that a cellular factor, $c-m y b$, can interact synergistically with the $\mathrm{Z}$ transactivator in lymphoid cells.

There are several lines of evidence to suggest that transcriptional activation by the c-myb or v-myb protein may involve interactions with other cellular transcription factors. First, in a recent report by Ibanez and Lipsick (24), the authors found that binding of the viral myb protein to consensus Myb binding sites was required but not sufficient for activation of linked reporter genes and concluded that transactivation by $v-m y b$ may require interaction with another DNA-bound transcription factor. Second, the Mybrelated BAS1 protein in Saccharomyces cerevisiae activates the HIS4 gene only in cooperation with a second transcription factor, BAS2 (a homeodomain protein) (53). Third, the transforming effects of $\mathrm{v}-m y b$ are highly tissue specific, suggesting that interactions with tissue-specific factors are likely to be required for the transcriptional effects of the $m y b$ proteins. Fourth, at least one promoter (the heat shock promoter) can be activated by v-myb through a mechanism that does not appear to involve direct DNA binding (27) and therefore is likely to be mediated through interaction with cellular transcription factors.

At this point, the exact mechanism by which the $\mathrm{Z}$ and $c-m y b$ proteins can synergistically interact to stimulate BMRF1 and SV40 promoters in lymphoid cells, but not epithelial cells, is not determined. Although our data do not totally exclude the possibility that this effect is due to the ability of $\mathrm{Z}$ to enhance c-myb-induced transactivation, it seems much more likely that for the BMRF1 promoter, at least, it is c-myb which enhances $\mathrm{Z}$-induced transactivation. $\mathrm{Z}$ binding to the BMRF1 promoter appears to be a crucial element in this interaction, since (i) destruction of the AP-1 site by either $5^{\prime}$ deletion or site-directed mutation of the BMRF1 promoter significantly decreases the combined effect of the Z/c-myb combination on BMRF1 promoter activity, (ii) simultaneous destruction of both $\mathrm{Z}$ binding sites (the AP-1 site and the upstream ZRE) totally abolishes the $\mathrm{Z} / \mathrm{c}-\mathrm{myb}$ effect, and (iii) a site-directed mutation in the $\mathrm{Z}$ protein which impairs DNA binding but does not affect protein stability or nuclear localization also abolishes the ability of $\mathrm{Z}$ to interact synergistically with c- $m y b$.

The mechanism by which c-myb contributes to Z-induced transactivation of the BMRF1 and SV40 promoters is not yet clear. Our data suggest that direct $\mathrm{c}-\mathrm{Myb}$ binding to the BMRF1 promoter is unlikely, given that we were unable to demonstrate binding in vitro, and mutation of the most likely potential c-Myb binding in the promoter did not diminish the combined effect of $\mathrm{Z}$ and c-myb. However, deletion of the DNA binding domain in the c-myb protein did abolish the ability of $c-m y b$ to interact synergistically with $\mathrm{Z}$. This requirement for the c-Myb DNA binding domain could reflect an indirect mechanism involving activation by c-myb of another cellular transcription factor, rather than direct c-Myb binding to the BMRF1 promoter. Alternatively, the amino-terminal domain of c-Myb may encode other func- tions in addition to DNA binding. The latter possibility is suggested in a recent report by Lane et al. (32), who found that a linker insertion mutation within the DNA binding domain of $\mathrm{v}-\mathrm{Myb}$, which did not affect DNA binding capacity or nuclear localization, nevertheless inhibited transactivation and transformation by v-myb. Given that we have not yet confirmed that our particular mutant localizes to the nucleus in Jurkat cells, it is still a possibility that inability of this mutant c-myb protein to enter the nucleus explains our results.

Interestingly, the SV40 early promoter has been previously found to contain a number of functional Myb binding sites (40). One of the weakest binding sites in SV40, designated MBS II, is present within the pA10CAT construct used in these experiments, and like the potential Myb binding site in the BMRF1 promoter, the MBS II site overlaps an AP-1 site (33). This finding suggests that the $\mathrm{Z} / \mathrm{c}-\mathrm{my} b$ effect on the SV40 promoter may indeed be mediated by a mechanism involving binding of both proteins to this promoter, and that perhaps we were unable to detect $\mathrm{v}$-Myb binding to the BMRF1 promoter because binding to this site is weaker than binding to the consensus site. It is possible that c-Myb binding to sites which are relatively weak in vitro (such as the MBS II site) is stabilized by interactions with cellular factors in vivo. However, the MBS II site, when multimerized and linked to a heterologous promoter, was found to confer negative regulation in the presence of $c-m y b$ in CV1 cells (40). Therefore, the effect of a particular Myb binding site on promoter activity may well depend on the cell type tested, the relative proportions of the different members of the Myb family of proteins (A-Myb versus B-Myb versus $\mathrm{c}-\mathrm{Myb}$ ), and the presence or absence of nearby binding sites for other transcription factors.

Our data suggest the possibility that protein-protein interactions occur between c-myb and $\mathrm{Z}$. Recent reports from several laboratories have demonstrated protein-protein interactions between AP-1 and the glucocorticoid receptor (9, 60 ), and these interactions do not necessarily require binding sites for both proteins. In addition, the papillomavirus E2 protein has been recently shown to directly interact with the $\mathrm{Sp} 1$ transcription factor, and this interaction is observed if either an E2 binding site or an Sp1 binding site is present (34). These results offer a precedent for the interaction observed here between $\mathrm{Z}$ and c-myb in which the c-myb protein does not appear to bind to the relevant promoter. Interestingly, the carboxy-terminal half of $\mathrm{c}-\mathrm{Myb}$, which has been shown to function as a negative regulator of c-myb transactivation (46), contains a putative leucine zipper motif and could potentially interact with the $\mathrm{Z}$ protein through this region. Alternatively, protein-protein interactions between $c-m y b$ and $\mathrm{Z}$ might involve the DNA binding domain of $\mathrm{c}-\mathrm{Myb}$, which was found in this study to be required for synergy with $Z$. At this point, however, we have no evidence that direct protein-protein interactions between $\mathrm{Z}$ and c-myb occur. Specifically, we have not found that the combination of $\mathrm{Z}$ and $c-m y b$ affects $\mathrm{Z}$ or c-myb protein binding to the BMRF1 promoter in vitro $(25 a)$.

Regardless of the precise mechanism, our demonstration that the $c-m y b$ protein can interact synergistically with $\mathrm{Z}$ to activate not only the EBV BMRF1 promoter but also the SV40 early promoter suggests that c-myb is likely to have similar synergistic interactions with cellular transcription factors. Whether the synergistic interaction demonstrated here between $\mathrm{Z}$ and c-myb is important in EBV infection remains to be determined. We have preliminary data that several other EBV early promoters are transactivated more 
efficiently in lymphoid cells by the combination of $\mathrm{Z}$ and $c-m y b$ than by $Z$ alone $(25 \mathrm{a})$. It is known that c-myb expression in pre-B cells is much higher than in mature $B$ cells (1). Interestingly, EBV infection of precursor B-cell lines has been shown to be unusually productive in comparison with infection of mature B-cell lines (18), suggesting that the high constitutive expression of $c-m y b$ in precursor $B$ cells might facilitate productive viral infection.

The ability of $\mathrm{Z}$ alone to function efficiently in HeLa cells but not Jurkat cells is somewhat paradoxical, since the level of endogenous c-myb would be expected to be higher in Jurkat cells (38). However, it is quite possible that the level of total $m y b$ activity (including A-myb and B-myb) is higher in HeLa cells, accounting for the increased efficiency of $\mathrm{Z}$ in this cell type. The B-myb gene product, which is present in a wide variety of cells (42), is now known to bind to c-Myb binding sites and function as a transcriptional transactivator (39). We do not yet know whether B-myb, like c-myb, can interact synergistically with the $\mathrm{Z}$ transactivator. Since HeLa cells are known to contain papillomavirus, it is also possible that a papillomavirus-encoded protein can substitute for the c-Myb function. Alternatively, the inherent differences in the transcriptional environment in Jurkat versus $\mathrm{HeLa}$ cells may dictate a requirement for c-myb helper function in the first cell type which is unnecessary in the second.

There is some evidence that an EBV-encoded IE gene product, BRLF1(R) $(19,20)$, may provide a functional substitute for $c-m y b$ in activation of the BMRF1 promoter. We have previously shown that the $R$ gene product, like $c-M y b$, can interact synergistically with $\mathrm{Z}$ in activating the BMRF1 promoter in lymphoid cells but not epithelial cells (21). We have also found that the $\mathrm{R}$ transactivator effect on $\mathrm{c}-m y c$ promoter regulation is similar to the previously described effect of c-Myb $(10,19 a)$. However, the functional similarities between $\mathbf{R}$ and c-Myb are clearly limited, in that we have been unable to show that the $R$ transactivator activates promoter constructs containing multiple copies of the consensus myb response element or that c-Myb transactivates promoter constructs containing known R-responsive targets $(5,8,25 a, 26)$.

The data presented in this report emphasize that activation of responsive promoters by $\mathrm{Z}$ is likely to involve not only the requirement for $\mathrm{Z}$ binding to these promoters but also complex interactions between the $\mathrm{Z}$ protein and cellular transcription factors. It appears that the cooperative interaction of $\mathrm{Z}$ with other transcription factors (either the virally encoded $\mathbf{R}$ transactivator or the cellularly encoded c-myb transactivator) is required for maximal $\mathrm{Z}$ effect on the BMRF1 promoter in lymphoid cells.

\section{ACKNOWLEDGMENTS}

This work was supported by Public Health Service grants K08CA01229-03 and 5-P01-CA19014-12 from the National Institutes of Health and grant MV-532 from the American Cancer Society.

We thank Gloria Majette for preparation of the manuscript and Joseph Pagano for reviewing the manuscript.

\section{REFERENCES}

1. Bender, T., and M. Kuehl. 1987. Differential expression of the c-myb proto-oncogene marks the pre-B cell/B cell junction in murine B lymphoid tumors. J. Immunol. 139:3822-3827.

2. Biedenkapp, H., U. Borgmeyer, A. E. Sippel, and K. H. Klempnauer. 1988. Viral myb oncogene encodes a sequence-specific DNA-binding activity. Nature (London) 335:835-837.

3. Boyle, W., J. Lipsick, and M. Baluda. 1986. Antibodies to the evolutionarily conserved amino-terminal region of the v-myb- encoded protein detect the $c$-myb protein in widely divergent metazoan species. Proc. Natl. Acad. Sci. USA 83:4685-4689.

4. Chang, Y.-N., D. Dong, G. Hayward, and S. D. Hayward. 1990. The Epstein-Barr virus Zta transactivator: a member of the bZip family with unique DNA-binding specificity and a dimerization domain that lacks the characteristic heptad leucine zipper motif. J. Virol. 64:3358-3369.

5. Chevallier-Greco, A., H. Gruffat, E. Manet, A. Calender, and A. Sergeant. 1989. The Epstein-Barr virus (EBV) DR enhancer contains two functionally different domains: domain $\mathrm{A}$ is constitutive and cell specific, domain $B$ is transactivated by the EBV early protein R. J. Virol. 63:615-623.

6. Chevallier-Greco, A., H. Gruffat, E. Manet, P. Chavrier, C. Mosnier, J. Daillie, and A. Sergeant. 1986. Both Epstein-Barr virus (EBV)-encoded transactivators, EB1 and EB2, are required to activate transcription from an EBV early promoter. EMBO J. 5:3243-3249.

7. Countryman, J., H. Jenson, R. Seibl, H. Wolf, and G. Miller. 1987. Polymorphic proteins encoded within the BZLF1 of defective and standard Epstein-Barr viruses disrupt latency. J. Virol. 61:3672-3679.

8. Cox, M. A., J. Leahy, and J. M. Hardwick. 1990. An enhancer within the divergent promoter of Epstein-Barr virus responds synergistically to the $\mathrm{R}$ and $\mathrm{Z}$ transactivators. J. Virol. 64:313321.

9. Diamond, M., J. Miner, S. Yoshinaga, and K. Yamamoto. 1990. Transcription factor interactions: selectors of positive or negative regulation from a single DNA element. Science 249:12661272.

10. Evans, J. L., T. L. Moore, W. M. Kuehl, T. Bender, and J. P.-Y. Ting. 1990. Functional analysis of c-Myb protein in T-lymphocytic cell lines shows that it trans-activates the c-myc promoter. Mol. Cell. Biol. 10:5747-5752.

11. Farrell, P., D. Rowe, C. Rooney, and J. T. Kouzarides. 1989. Epstein-Barr virus BZLF1 trans-activator specifically binds to consensus AP-1 site and is related to c-fos. EMBO J. 8:127-132.

12. Favaloro, J., R. Treisman, and R. Kamen. 1980. Transcription maps of polyoma virus-specific RNA; analysis by two dimensional S1 gel mapping. Methods Enzymol. 65:718-728.

13. Flemington, E., and S. H. Speck. 1990. Autoregulation of Epstein-Barr virus putative lytic switch gene BZLF1. J. Virol. 64:1227-1232.

14. Garcia, A., K. Montagne, D. Reavis, U. Stober-Grasser, and J. Lipsick. 1991. Determinants of sequence-specific DNA-binding by p48 v-myb. Oncogene 6:265-273.

15. Gilman, M. 1988. Preparation of cytoplasmic RNA from tissue culture cells, p. 4.1.2-4.1.6. In F. M. Ausubel, R. Brent, R. E. Kingston, D. D. Moore, J. G. Seidman, J. A. Smith, and K. Struhl (ed.), Current protocols in molecular biology. Greene Publishing Associates and Wiley Interscience, New York.

16. Giot, J.-F., I. Mikaelian, M. Buisson, E. Manet, I. Joab, J.-C. Nicolas, and A. Sergeant. 1991. Transcriptional synergy and interference between the EBV transcription factors EB1 and $R$ require both the basic region and the activation domain 2 of EB1. Nucleic Acids Res. 19:1251-1258.

17. Gorman, C. M., L. F. Moffat, and B. H. Howard. 1982. Recombinant genomes which express chloramphenicol acetyltransferase in mammalian cells. Mol. Cell. Biol. 2:1044-1051.

18. Gregory, C., C. Kirchgens, C. Edwards, L. Young, M. Rowe, A. Forster, T. Rabbits, and A. Rickenson. 1987. Epstein-Barr virus-transformed human precursor B cell lines: altered growth phenotype of lines with germ-line or rearranged but nonexpressed heavy chain genes. Eur. J. Immunol. 17:1199-1207.

19. Gruffat, H., E. Manet, A. Rigolet, and A. Sergeant. 1990. The enhancer factor $R$ of Epstein-Barr virus (EBV) is a sequencespecific DNA binding protein. Nucleic Acids Res. 18:68356843.

19a.Gutsch, D. Unpublished data.

20. Hardwick, J. M., P. Lieberman, and S. D. Hayward. 1988. A new Epstein-Barr virus transactivator, $R$, induces expression of a cytoplasmic early antigen. J. Virol. 62:2274-2284.

21. Holley-Guthrie, E., E. B. Quinlivan, E.-C. Mar, and S. Kenney. 1990. The Epstein-Barr virus promoter for early antigen (EA-D) 
is regulated by the EBV transactivators, BRLF1 and BZLF1, in a cell-specific manner. J. Virol. 64:3753-3759.

22. Howe, K. M., C. F. L. Reakes, and R. J. Watson. 1990. Characterization of the sequence-specific interaction of mouse c-myb protein with DNA. EMBO J. 9:161-169.

23. Ibanez, C., and J. Lipsick. 1988. Structural and functional domains of the myb oncogene: requirements for nuclear transport, myeloid transformation, and colony formation. J. Virol. 62:1981-1988.

24. Ibanez, C., and J. Lipsick. 1990. Transactivation of gene expression by v-myb. Mol. Cell. Biol. 10:2285-2293.

25. Introna, M., J. Golay, J. Frampton, T. Nakano, S. Ness, and T. Graf. 1990. Mutations in v-myb alter the differentiation of myelomonocytic cells transformed by the oncogene. Cell 63: 1287-1297.

25a.Kenney, S. Unpublished data.

26. Kenney, S., E. Holley-Guthrie, E. C. Mar, and M. Smith. 1989. The Epstein-Barr virus BMLF1 promoter contains an enhancer element that is responsive to the BZLF1 and BRLF1 transactivators. J. Virol. 63:3878-3883.

27. Klempnauer, K.-H., H. Arnold, and H. Biedenkapp. 1989. Activation of transcription by v-myb: evidence for two different mechanisms. Genes Dev. 3:1582-1589.

28. Klempnauer, K.-H., and A. E. Sippel. 1987. The highly conserved amino-terminal region of the protein encoded by the $\mathrm{v}$-myb oncogene functions as a DNA-binding domain. EMBO J. 6:2719-2725.

29. Kouzarides, T., G. Packham, A. Cook, and P. Farrell. 1991. The BZLF1 protein of EBV has a coiled coil dimerization domain without a heptad leucine repeat but homology to the C/EBP leucine zipper. Oncogene 6:195-204.

30. Kunkel, T. A. 1985. Rapid and efficient site-specific mutagenesis without phenotypic selection. Proc. Natl. Acad. Sci. USA 82:488-492.

31. Laimins, L., P. Gruss, R. Pozatti, and G. Khoury. 1984. Characterization of enhancer elements in the long terminal repeat of Moloney murine sarcoma virus. J. Virol. 49:183-189.

32. Lane, T., C. Ibanez, A. Garcia, T. Graf, and J. Lipsick. 1990. Transformation by $\mathrm{v}-\boldsymbol{m y b}$ correlates with transactivation of gene expression. Mol. Cell. Biol. 10:2591-2598.

33. Lee, W., P. Mitchell, and R. Tjian. 1987. Purified transcription factor AP-1 interacts with TPA-inducible enhancer elements. Cell 49:741-752.

34. Li, R., J. Knight, S. Jackson, R. Tjian, and M. Botchan. 1991. Direct interaction between the Sp1 and the BPV enhancer E2 protein mediates synergistic activation of transcription. Cell 65:493-505.

35. Lieberman, P., and A. Berk. 1990. In vitro transcriptional activation, dimerization, and DNA-binding specificity of the Epstein-Barr virus Zta protein. J. Virol. 64:2560-2568.

36. Lillie, J., and M. Green. 1989. Transcription activation by the adenovirus Ela protein. Nature (London) 338:39-44.

37. Lipsick, J. S., and W. J. Boyle. 1987. c-myb expression is a late event during T-lymphocyte activation. Mol. Cell. Biol. 7:33583360.

38. Luscher, B., and B. Eisenman. 1990. New light on myc and myb. Part II. Myb. Genes Dev. 4:2235-2241.

39. Mizuguchi, G., H. Nakagoshi, T. Nagase, N. Nomura, T. Date, Y. Ueno, and S. Ishii. 1990. DNA binding activity and transcriptional activator function of the human B-myb protein compared with c-myb. J. Biol. Chem. 265:9280-9284.

40. Nakagoshi, H., T. Nagase, Y. Ueno, and S. Ishii. 1989. Transcriptional transrepression by the c-myb proto-oncogene product. Nucleic Acids Res. 17:7315-7324.

41. Nishina, Y., H. Nakagoshi, F. Imamoto, T. J. Gonda, and S. Ishii. 1989. Trans-activation by the c-myb proto-oncogene. Nucleic Acid Res. 17:107-117.

42. Nomura, N., M. Takahashi, M. Matsui, S. Ishii, T. Date, S.
Sasamoto, and R. Ishizaki. 1988. Isolation of human cDNA clones of myb-related genes, A-myb and B-myb. Nucleic Acid Res. 16:11075-11085.

43. Packham, G., A. Economou, C. Rooney, D. Rowe, and P. Farrell. 1990. Structure and function of the Epstein-Barr virus BZLF1 protein. J. Virol. 64:2110-2116.

43a.Quinlivan, E., et al. Submitted for publication.

44. Rooney, C., N. Taylor, J. Countryman, H. Jenson, J. Kolman, and G. Miller. 1988. Genome rearrangements activate the Epstein-Barr virus gene whose product disrupts latency. Proc. Natl. Acad. Sci. USA 85:9801-9805.

45. Rooney, C. M., D. T. Rowe, T. Ragot, and P. J. Farrell. 1989. The spliced BZLF1 gene of Epstein-Barr virus (EBV) transactivates an early EBV promoter and induces the virus productive cycle. J. Virol. 63:3109-3116.

46. Sakura, H., C. Kanei-Ishii, T. Nagase, H. Nakagoshi, T. Gonda, and S. Ishii. 1989. Delineation of three functional domains of the transcriptional activator encoded by the c-myb proto-oncogene. Proc. Natl. Acad. Sci. USA 86:5758-5762.

47. Shen-ong, G., B. Luscher, and R. Eisenman. 1989. A second c- $m y b$ protein is translated from an alternatively spliced mRNA expressed from normal and 5' disrupted myb loci. Mol. Cell. Biol. 9:5456-5463.

48. Takada, K., N. Shimuzu, S. Sakuma, and Y. Ono. 1986. Transactivation of the latent Epstein-Barr virus (EBV) genome after transfection of the EBV DNA fragment. J. Virol. 57:1016-1022.

49. Takimoto, T., H. Ogura, H. Sato, R. Umeda, and M. Hatano. 1985. Isolation of transforming and early antigen-producing Epstein-Barr virus from nasopharyngeal carcinoma hybrid cells (NPC-KT). J. Natl. Cancer Inst. 74:57-59.

50. Taylor, N., E. Flemington, J. Kolman, R. Baumann, S. Speck, and G. Miller. 1991. ZEBRA and a Fos-GCN4 chimeric protein differ in their DNA-binding specificities for sites in the EpsteinBarr virus BZLF1 promoter. J. Virol. 65:4033-4041.

51. Thiele, C., P. S. Cohen, and M. S. Israel. 1988. Regulation of c-myb expression in human neuroblastoma cells during retinoic acid-induced differentiation. Mol. Cell. Biol. 8:1677-1683.

52. Thompson, C. B., P. B. Challoner, P. E. Neiman, and $M$. Groudine. 1986. Expression of the c-myb proto-oncogene during cellular proliferation. Nature (London) 319:374-380.

53. Tice-Baldwin, K., G. Fink, and K. Arndt. 1989. BAS1 has an Myb motif and activates HIS4 transcription only in combination with BAS2. Science 246:931-935.

54. Tonneguzzo, F., A. C. Hayday, and A. Keating. 1986. Electric field-mediated DNA transfer: transient and stable gene expression in human and mouse lymphoid cells. Mol. Cell. Biol. 6:703-706

55. Urier, G., M. Buisson, P. Chambard, and A. Sergeant. 1989. The Epstein-Barr virus early protein EB1 activates transcription from different responsive elements including AP-1 binding sites. EMBO J. 8:1447-1453.

56. Vinson, C. R., P. B. Sigler, and S. L. McKnight. 1989. Scissorsgrip model for DNA recognition by a family of leucine zipper proteins. Science 246:911-916.

57. Weber, B., E. Westin, and M. Clarke. 1990. Differentiation of mouse erythroleukemia cells enhanced by alternatively spliced c-myb mRNA. Science 249:1291-1293.

58. Westin, E., K. Gorse, and M. Clarke. 1990. Alternative splicing of the human c-myb gene. Oncogene 5:1117-1124.

59. Weston, K., and J. M. Bishop. 1989. Transcriptional activation by the v-myb oncogene and its cellular progenitor, c-myb. Cell 58:85-93.

60. Yang-Yen, H.-F., J.-C. Chambard, Y.-L. Sun, T. Smeal, T. Schmidt, J. Drouin, and M. Karin. 1990. Transcription interference between c-Jun and glucocorticoid receptor: mutual inhibition of DNA-binding due to direct protein-protein interaction. Cell 62:1205-1215. 